\title{
Sexual-biased gene expression of olfactory- related genes in the antennae of Conogethes pinicolalis (Lepidoptera: Crambidae)
}

Dapeng Jing ${ }^{1,2}$, Tiantao Zhang ${ }^{1 *}$ (D), Shuxiong Bai ${ }^{1}$, Kanglai He ${ }^{1}$, Sivaprasath Prabu', Junbo Luan ${ }^{2}$ and Zhenying Wang ${ }^{1 *}$

\begin{abstract}
Background: Conogethes pinicolalis (Lepidoptera: Crambidae), is similar to Conogethes punctiferalis (yellow peach moth) and its host plant is gymnosperms, especially for masson pine. So far, less literature was reported on this pest. In the present study, we sequenced and characterized the antennal transcriptomes of male and female $C$. pinicolalis for the first time.

Results: Totally, 26 odorant-binding protein (OBP) genes, 19 chemosensory protein (CSP) genes, 55 odorant receptor (OR) genes and 20 ionotropic receptor (IR) genes were identified from the C. pinicolalis antennae transcriptome and amino sequences were annotated against homologs of $C$. punctiferalis. The neighbor-joining tree indicated that the amino acid sequence of olfactory related genes is highly homologous with C. punctiferalis. Furthermore, the reference genes were selected, and we recommended the phosphate dehydrogenase gene (GAPDH) or ribosomal protein 49 gene (RP49) to verify the target gene expression during larval development stages and RP49 or ribosomal protein L13 gene (RPL13) for adult tissues.
\end{abstract}

Conclusions: Our study provides a starting point on the molecular level characterization between C. pinicolalis and C. punctiferalis, which might be supportive for pest management studies in future.

Keywords: Conogethes pinicolalis, Conogethes punctiferalis, Yellow peach moth, Transcriptomics, OBP, GOBP, PBP, RNA-Seq, Transcriptome

\section{Background}

Olfaction system plays a key role in insects, which includes kin recognition, mediating foraging, aggregation, toxic compound avoidance and oviposition behaviors. However, the olfaction is a complex network that contains odorant-binding proteins (OBP), odorant receptors (OR), chemosensory proteins (CSP),

\footnotetext{
* Correspondence: zhtiantao@163.com; zywang@ippcaas.cn

${ }^{1}$ State Key Laboratory for Biology of Plant Diseases and Insect Pests, Institute of Plant Protection, Chinese Academy of Agricultural Sciences, Beijing 100193, China

Full list of author information is available at the end of the article
}

sensory neuron membrane proteins (SNMPs), ionotropic receptors (IR) and odorant degrading enzymes (ODEs). They form a functional network with each other in detecting different odorants types, thus complete the odorants recognition process $[1,2]$. In Lepidoptera, OBPs are composed of pheromonebinding proteins (PBPs), general odorant-binding proteins (GOBPs) and antennal binding proteins (ABPs), and they combined to detect a wide range of odors and transport hydrophobic odorants to the ORs or IRs [3]. The functions of CSPs are also similar to

C C The Author(s). 2020 Open Access This article is licensed under a Creative Commons Attribution 4.0 International License, which permits use, sharing, adaptation, distribution and reproduction in any medium or format, as long as you give appropriate credit to the original author(s) and the source, provide a link to the Creative Commons licence, and indicate if changes were made. The images or other third party material in this article are included in the article's Creative Commons licence, unless indicated otherwise in a credit line to the material. If material is not included in the article's Creative Commons licence and your intended use is not permitted by statutory regulation or exceeds the permitted use, you will need to obtain permission directly from the copyright holder. To view a copy of this licence, visit http://creativecommons.org/licenses/by/4.0/ The Creative Commons Public Domain Dedication waiver (http://creativecommons.org/publicdomain/zero/1.0/) applies to the data made available in this article, unless otherwise stated in a credit line to the data. 
OBPs, localized in the lymph of trochoid sensilla [4]. IRs or ORs are localized on the dendrite of the chemosensory neuron, which can transform the chemical signals from OBPs or CSPs into an electric signal and transmit to the brain $[5,6]$. The SNMPs and ODEs are regarded to trigger ligand delivery to the receptor and terminate the signal stimulation, respectively [6].

Conogethes pinicolalis (Lepidoptera: Crambidae), is a sibling species of Conogethes punctiferalis (Lepidoptera: Crambidae). Morphological features of $C$. pinicolalis egg, larva, pupa and adult resemble those of $C$. punctiferalis and it is considered as same species. In 1963, Koizumi firstly identified the $C$. pinicolalis as an another type of yellow peach moth and classified as pinaceaefeeding type (PFT) [7]. Later, Honda and Mitsuhashi identified and distinguished the difference between these pests in the adults, larvae and pupal stages [8]; Konno et al. reported that they were different species from their response to different spectra of host-plant constituents [9]; In 2006, the pinaceae-feeding type was named as C. pinicolalis [10]. Though these studies have provided important information regarding the identification of species, it is not entirely reliable because these insect groups were undergoing speciation, genomic changes, or evolving into new taxon [11]. Therefore, for its high reliability, molecular characterization technique can serve as a complementary method for further analysis. Especially, DNA sequencing and mitochondrial DNA (mtDNA) have been successfully used to deal with the species uncertainty in morphological taxonomy [12-14]. For example, Shashank integration of conventional taxonomy, DNA bar code and others methods successfully confirmed the difference in populations of Conogethes which reared on castor and cardamom in India [11]. Furthermore, Wang et al. used mitochondrial DNA sequencing technique to verify $C$. pinicolalis and $C$. punctiferalis were significantly different species [15].

C. pinicolalis is a typical oligophagous pest that can only feed on Pinus massoniana (masson pine) and few pine trees. However, as a sibling species, C. punctiferalis, is a polyphagous pest that can infest hundreds of plants $[9,16]$. High-throughput sequencing technology can provide us with a lot of data and it has greatly promoted the research on entomology $[17,18]$. In this study, we analyzed the difference of male and female antennae transcriptome and identified the olfactory genes from Gene Ontology (GO) annotation as well as sets of putative OBPs, CSPs, ORs and IRs in C. pinicolalis. Furthermore, we compared the difference of the genes with $C$. punctiferalis. These results provide basically data for the study of $C$. pinicolalis olfactory genes, also may help to better understand the genetic evolution between these two sibling species.

\section{Results}

Overall sequence analysis

A total of 78,199,136 and 75,969,652 raw reads were obtained from male and female antennae, respectively. We obtained 77,254,390 and 74,994,240 clean reads from male and female antennae after trimming adapter sequences, eliminating low-quality reads, and $\mathrm{N}$ represented sequences. A total of 98,214 unigenes were obtained with an average length of 815 bp and with a N50 of 2968 (Table 1). The raw reads of the C. pinicolalis are available from the SRA database (accession number: SRX5250688, SRX5250689, SRX5250690, SRX5250691, SRX5250692 and SRX5250693).

\section{Functional annotation of the $C$. pinicolalis antennal unigenes}

In total, 98,214 unigenes were successfully annotated in all databases (Table 2), including 47,089 (47.94\%) unigenes matched to known proteins and 33,852 unigenes (34.46\%) in the Swiss-Prot database. GO analysis was used to classify the biological process, molecular function and cellular components (Additional file 1: Figure S1A). Under the molecular function category, the genes expressed in the antennae were mostly related to binding, catalytic activity and transporter activity (Additional file 1: Figure S1B). From the Kyoto Encyclopedia of Genes and Genomes (KEGG) annotation, 10,298 unigenes were classified into five groups, cellular processes, environmental information processing, genetic information processing, metabolism and organismal systems (Additional file 1: Figure S1C).

\section{Olfactory-related genes in the $C$. pinicolalis antennae}

Totally, 26 OBP genes, 19 CSP genes, 55 OR genes and 20 IR genes were identified from the $C$. pinicolalis antennae (Additional file 2: Table S1). Among the identified OBP genes, we found 4 PBP, 2 GOBP and 20 other kinds of OBP genes. Furthermore, OBP and CSP genes are detected in male and female antennae and showed the significant differences in genes abundance $(P<0.05)$ (Fig. 1). Interestingly, PBP2, OBP13 and OBP15 are male biased expression, whereas the other PBPs (PBP1, PBP3 and PBP4), as well as GOBPs (GOBP1 and GOBP2) are female bias expression. Furthermore, two of the other

Table 1 Summary of assembled contigs and unigenes

\begin{tabular}{lll}
\hline Type (bp) & Contigs & Unigenes \\
\hline Total number & 121,650 & 98,214 \\
Total length & $160,640,609$ & $154,441,888$ \\
Min length & 201 & 201 \\
Mean length & 568 & 815 \\
Maximum length & 25,856 & 25,856 \\
N50 & 2825 & 2968 \\
N90 & 467 & 612 \\
\hline
\end{tabular}


Table 2 Summary of annotations of unigenes

\begin{tabular}{lll}
\hline Type (bp) & $\begin{array}{l}\text { Number of } \\
\text { Unigenes }\end{array}$ & Percentage (\%) \\
\hline Annotated in NR & 47,089 & 47.94 \\
Annotated in NT & 31,124 & 31.68 \\
Annotated in KO & 18,774 & 19.11 \\
Annotated in SwissProt & 33,852 & 34.46 \\
Annotated in PFAM & 37,710 & 38.39 \\
Annotated in GO & 37,882 & 38.57 \\
Annotated in KOG & 19,474 & 19.82 \\
Annotated in all Databases & 8967 & 9.13 \\
Annotated in at least one & 59,764 & 60.85 \\
Database & & 100 \\
Total Unigenes & 98,214 & \\
\hline
\end{tabular}

OBPs (OBP7 and OBP9) remained female biased expression (Fig. 1a). CSP genes (CSP4, CSP5, CSP14, CSP11 and CSP17) showed female biased expression and significantly different from the male (Fig. 1b), Other insignificantly expressed genes were shown in Additional file 2: Table S1.

In OR gene sets, 7 pheromones receptors (PRs) and 47 other ORs were identified in male and female antennae. Three PR genes (OR1, OR3 and OR6), as well as OR34, showed significantly higher expression in male antennae. However, a large number of ORs (about 18 genes) were significantly higher expression in female antennae. Especially the OR48 and OR53, are highly expressed in female antennae with differential fold change $(\mathrm{FC})>5$. Six ORs with $2.0<\mathrm{FC}<5.0$ $(P<0.05)$ and eight $\mathrm{ORs}$ with $1.5<\mathrm{FC}<2.0 \quad(P<0.05)$ (Fig. 2a). Three IR genes (IR75p2, IR75d and IR4) showed female biased expression $(p<0.05)$ and other four genes (IR2, IR75p2, IR75p, and IR64a) were male biased expression $(p<0.05)$ (Fig. 2b).

Significantly expressed genes were confirmed by quantitative real-time PCR (RT-qPCR) (Additional file 1: Figure S2). Expressions of female biased genes from class OBP (PBP1, PBP3, PBP4, GOBP1, GOBP2, OBP6, OBP7 and OBP9) were enormously consistent with the transcripts per kilobase million (TMP) values.. The same results were obtained in the expression of CSPs, ORs and IRs (Additional file 1: Figure S2).

\section{Phylogenetic analysis}

Phylogenetic trees were constructed by using 95 OBPs, 157 ORs, 89 CSPs and 59 IRs from different species of Lepidoptera (Fig. 3; Additional file 1: Figure S3). The GOBP/PBP genes sequences include six subgroups (GOBP1 and 2, PBP1-4) formed a conserved order (Fig. 3). Furthermore, OBPs, CSPs, ORs and IRs showed a very close relationship with C. punctiferlis, only a few CSPs and IRs clustered with other insects (Fig. 3; Additional file 1: Figure S3). Most of the olfactory related genes showed more than $90 \%$ identity. Moreover, 4 OBP, 5 OR, 2 IR and 2 CSP genes had 99\% sequence similarity with the $C$. punctiferlis (Table 3). ORs and IRs genes indicated the Ostrinia furnacalis is the next
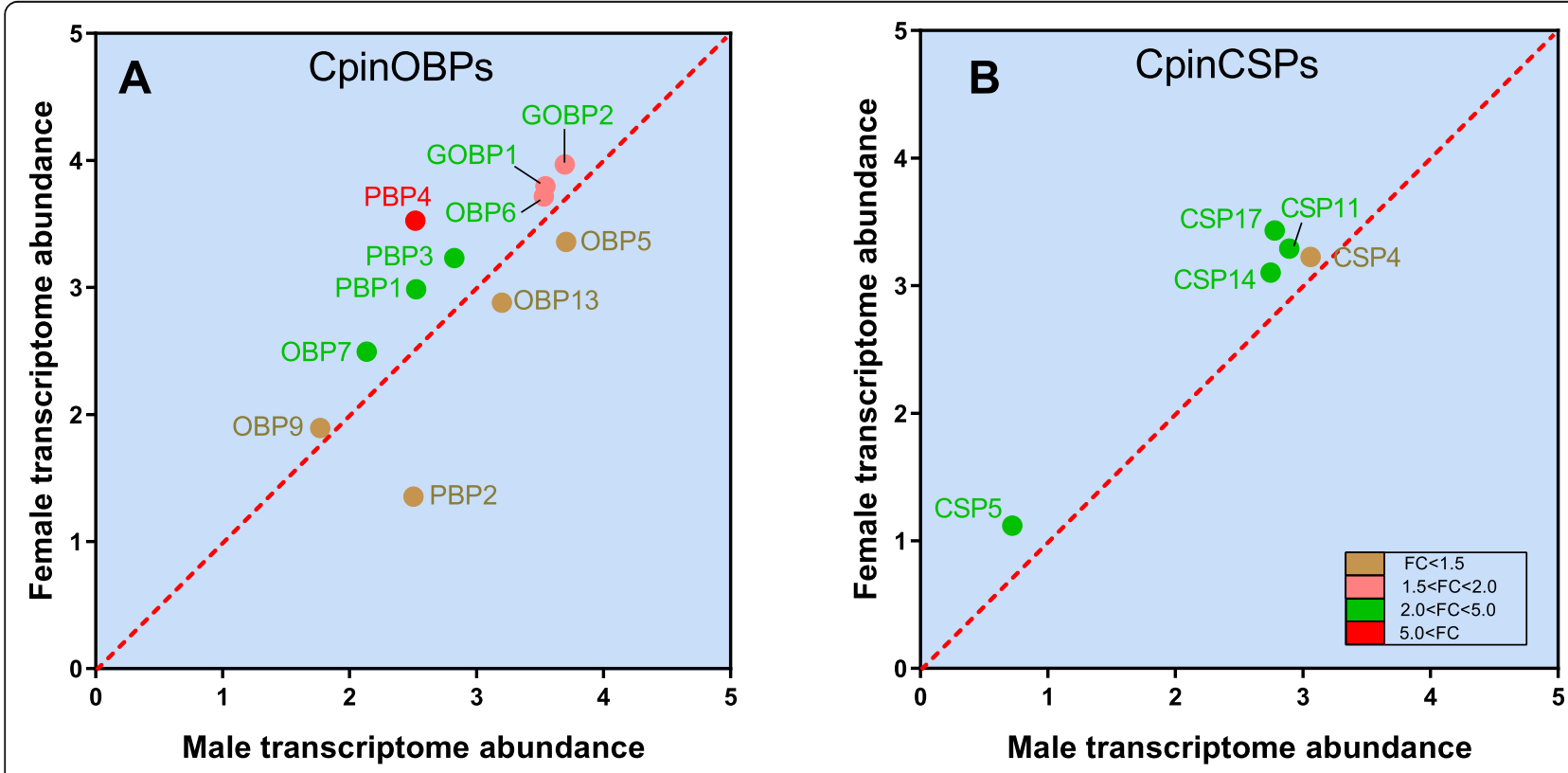

Fig. 1 Scatter plots showing the differential regulation of OBP and CSP genes in male and female C. pinicolalis antennae. Transcripts that exhibit significant differences in abundance $(P<0.05)$, are color-coded according to their weighted fold change $(F C)$. The expression levels are shown as the mean $\log 10(T P M+1)$ for all of the three biological replicates for both sexes 

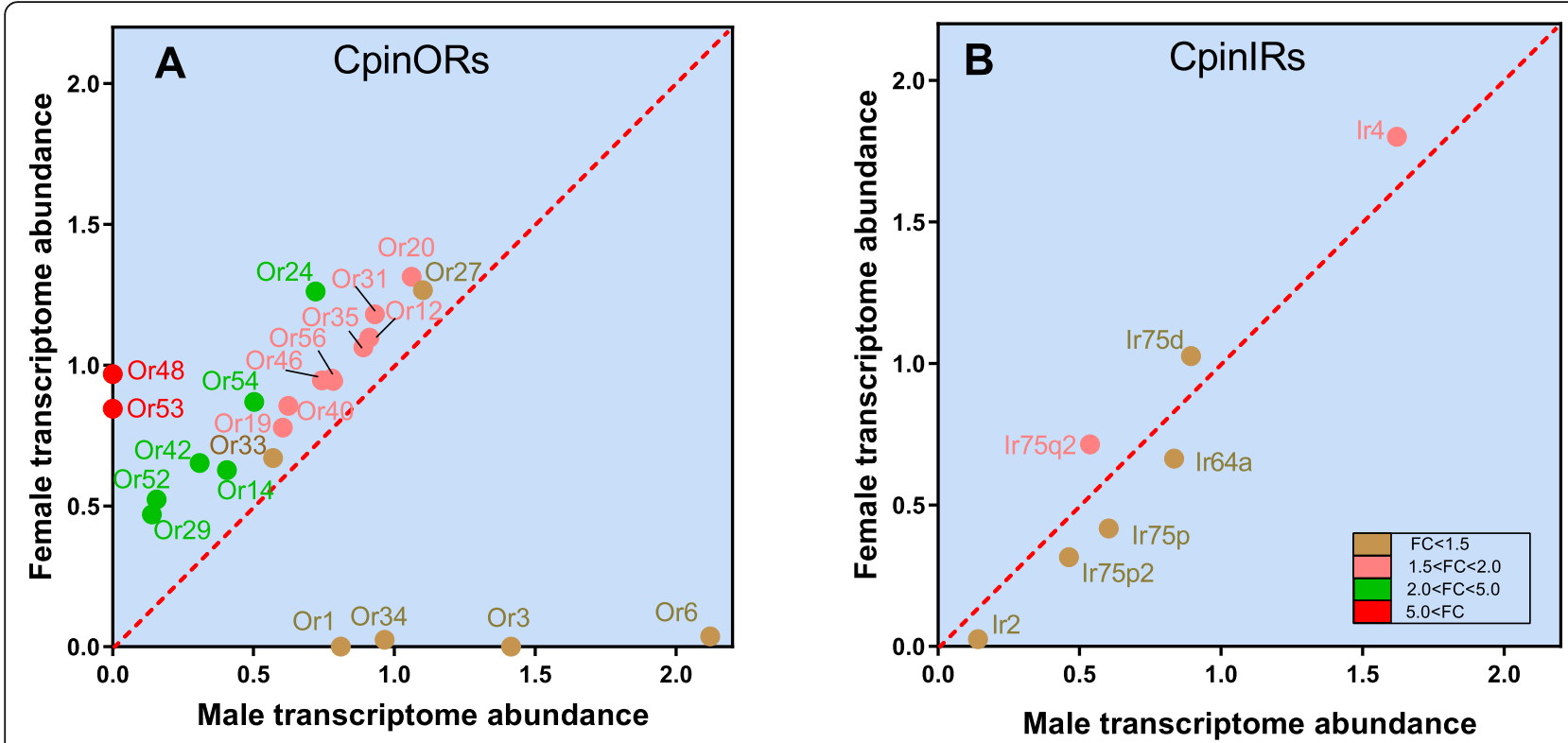

Fig. 2 Scatter plots showing the differential regulation of OBP and CSP genes in male and female C. pinicolalis antennae. Transcripts that exhibit significant differences in abundance $(P<0.05)$, are color-coded according to their weighted fold change $(F C)$. The expression levels are shown as the mean $\log 10(T P M+1)$ for all of the three biological replicates for both sexes

close neighbor in the same clade. On the other hand, OBPs and CSPs genes showed Cnaphalocrocis medinalisin in the same clade as a close neighbor after C. punctiferlis. Olfactory-related genes in Bombyx mori showed gene divergence when compared with these two sibling species.

\section{Reference genes selection}

The gene stability results obtained from both the software seems to be similar (Fig. 4). In the adult tissues (antanna, head, throax, abdomen, leg and wings) ribosomal protein 49 gene (RP49) and ribosomal protein L13 gene (RPL13) showed more stability than GADPH gene, and Actin gene was unstable (Fig. $4 \mathrm{~b}$ and d). However, RPL13 performed unstable in different development stages of the C. pinicolalis. The results of GeNorm software showed that Actin and phosphate dehydrogenase gene (GAPDH) are the most stable gene (Fig. 2a); while NormFinder software considered RP49 to be the most stable gene (Fig. 4b).

\section{Discussion}

The application of next-generation sequencing technology in the field of entomology has greatly promoted the efficiency and quantity of gene annotation [19]. Meantime, a lot of antennal transcriptomes olfactory-related genes were identified [20-22]. In this research, we identified 26 OBP genes, 19 CSP genes, 55 OR genes and 20 IR genes from the $C$. pinicolalis antennal transcriptome, these genes have been reported for the first time in this species. C. pinicolalis is a sibling species of $C$. punctiferlis, and had ever been recognized as the same species [10]. In C. punctiferlis, totally 25 OBPs, 15 CSPs, 62 ORs and 10 IRs were identified from antennae transcriptome [23], and the numbers of OBPs, CSPs and ORs are similar with $C$. pinicolalis, whereas more IRs were identified from the C. pinicolalis antennal transcriptome dataset, this may depend on the depth of the sequencing. The sequence similarity of olfactory-related genes was analyzed and shown in the evolution tree (Fig. 3, Table 3), OBP, CSP, OR and IR genes sequences showed high similarity with C. punctiferlis. Most of the identities are more than 90\%. 4 OBP, 5 OR, 2 IR and 2 CSP genes had 99\% sequence similarity with the C. punctiferlis (Table 3). These two pests were first identified by Koizumi et al. [7] and classified into pinaceae-feeding type (PFT) and fruitfeeding type (FFT) based on their feeding habits and morphological characters. They were later named as $C$. pinicolalis and C. punctiferalis [10]. Further investigation revealed their behaviors, morphologies, and feeding patterns, and indicated reproductive isolation between these two types $[9,16,18]$. Wang et al. have shown that the $C$. pinicolalis was different from that of $C$. punciferalis through mitochondrial cytochrome c oxidase subunits I, II and cytochrome $b$ gene sequences [15]. The phylogenetic tree also revealed an evolutionary relationship with other Lepidopteran species. The GOBP/PBP genes sequences include six subgroups (GOBP1 and 2, PBP1-4) formed a conserved order (Fig. 3). ORs and IRs genes indicated the Ostrinia furnacalis is also the close neighbor in the same clade (Additional file 1: Figure S3). On the other hand, 


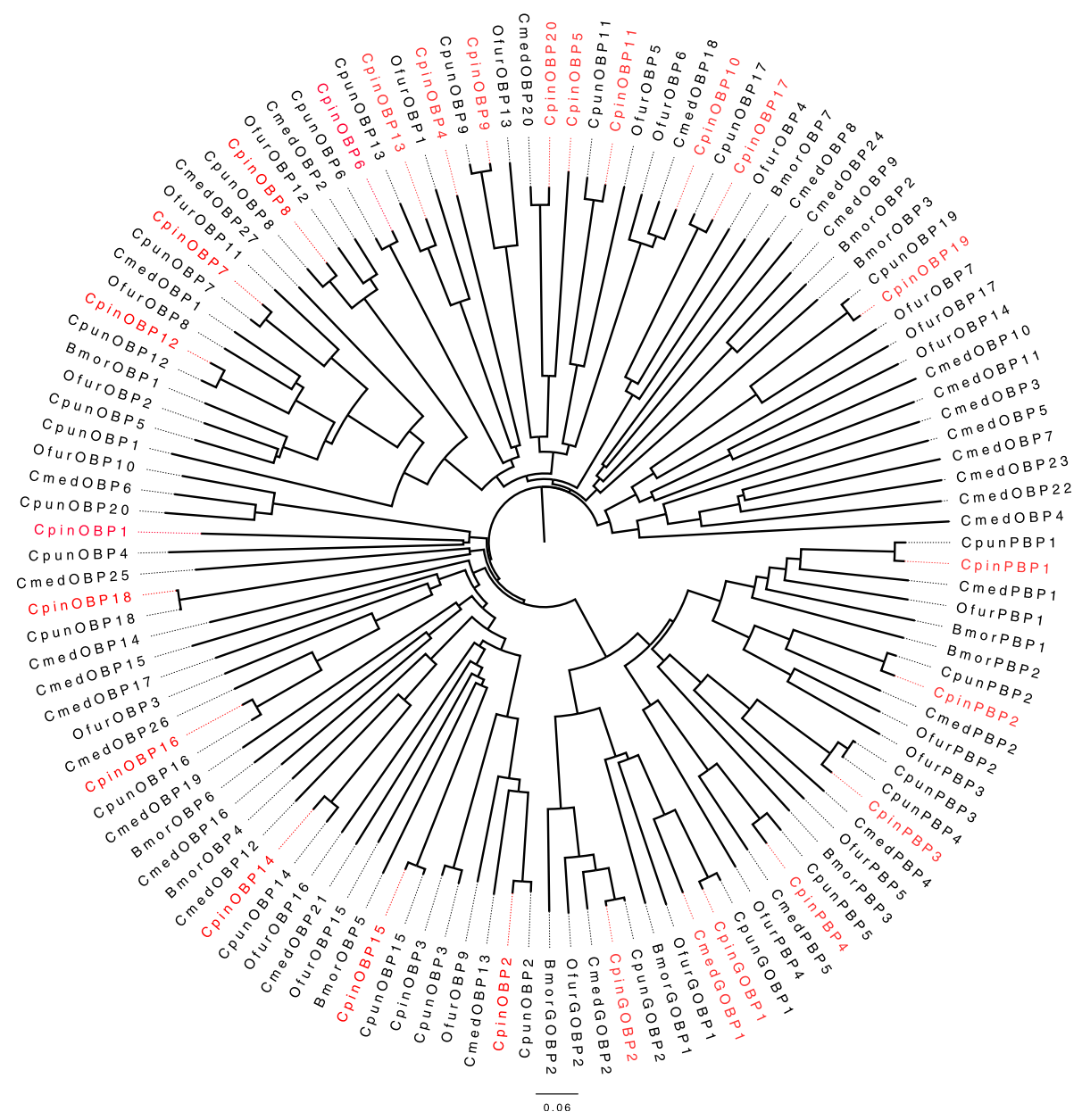

Fig. 3 Phylogenetic relationship of olfactory-related gene from C. pinicolalis and other insects. Red font represents the genes from C. pinicolalis; Cpun, Ofur, Bmor and Cmed are the abbreviation of C. punctiferalis, O. furnacalis, B. mori and Cnaphalocrocis medinalis, respectively

OBPs and CSPs genes showed Cnaphalocrocis medinalisin in the same clade as a close neighbor after C. punctiferlis. Olfactory-related genes in Bombyx mori showed gene divergence when compared with these two sibling species.

Menken et al. [24] suggested the two major transitions in the evolution of larval (Lepidoptera) feeding, switching from litter-feeding to herbivory. Larvae feeding on leaf-litter from a single dominant tree species would have been the main precursor for evolving from litter-feeding to leaf-mining type. In the course of evolution, leaf-mining type gained the new type of enzymatic system to digest the nutritious freshly fallen leaves. Once this evolved niche had been acquired the ability of leaf-mining and with the special digestive system could apparently exploit the diversity more and larval feeding mode had evolved in searching of new host-plants [25]. Insects olfaction system allows them to recognize and track the volatile cues from host-plant, mating and evade from their predators. The polyphagous insects significantly adapted to recognize, digest and detoxify a large variety of hostplants. Polyphagous insects must handle the defensive toxic molecules (secondary metabolites) produced by the host-plant. Genes from the moth pheromone glands could have evolved and altered the normal fatty acid metabolism [26]. In a previous study, experiments proved the major change in the pheromone blend in various moth species, the existence of different desaturase from mRNA in the moth pheromone gland [27]. In Spodoptera frugiperda, due to tandem duplications within a single region of the genome 10 OBP genes expansion was observed when compared with $B$. mori. In the same study, the author showed a difference in IRs gene count between the strains, $S$. frugiperda corn strain had 42 IRs and rice strain had 43 IRs [28]. Similarly, in our study C. pinicolalis had 10 more IRs when compared with C. punctiferlis. Evidently, the selection of host plant is also a reason that leads to gene duplications, insertions or deletions when there is a need to adapt to an environment. 


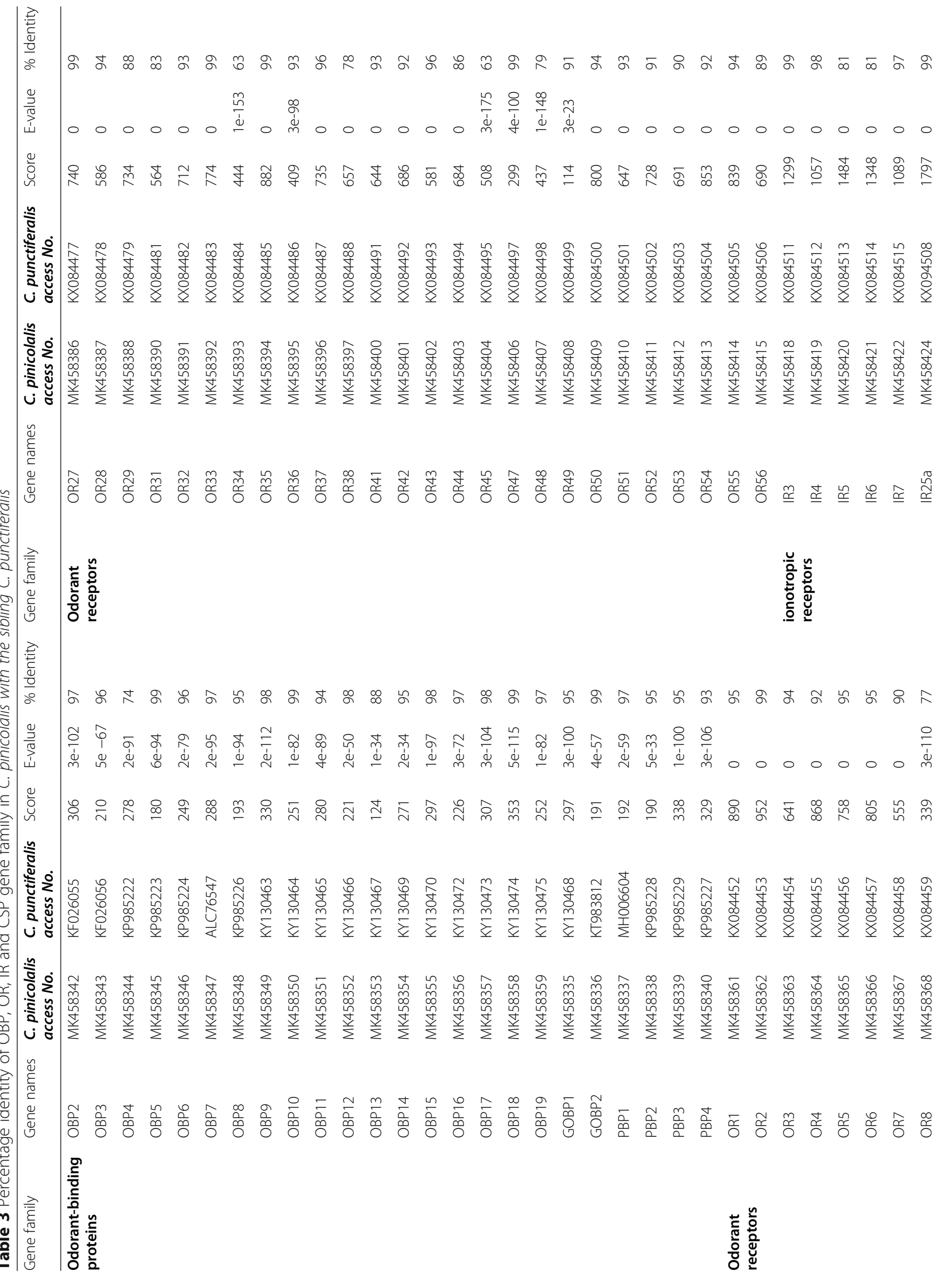




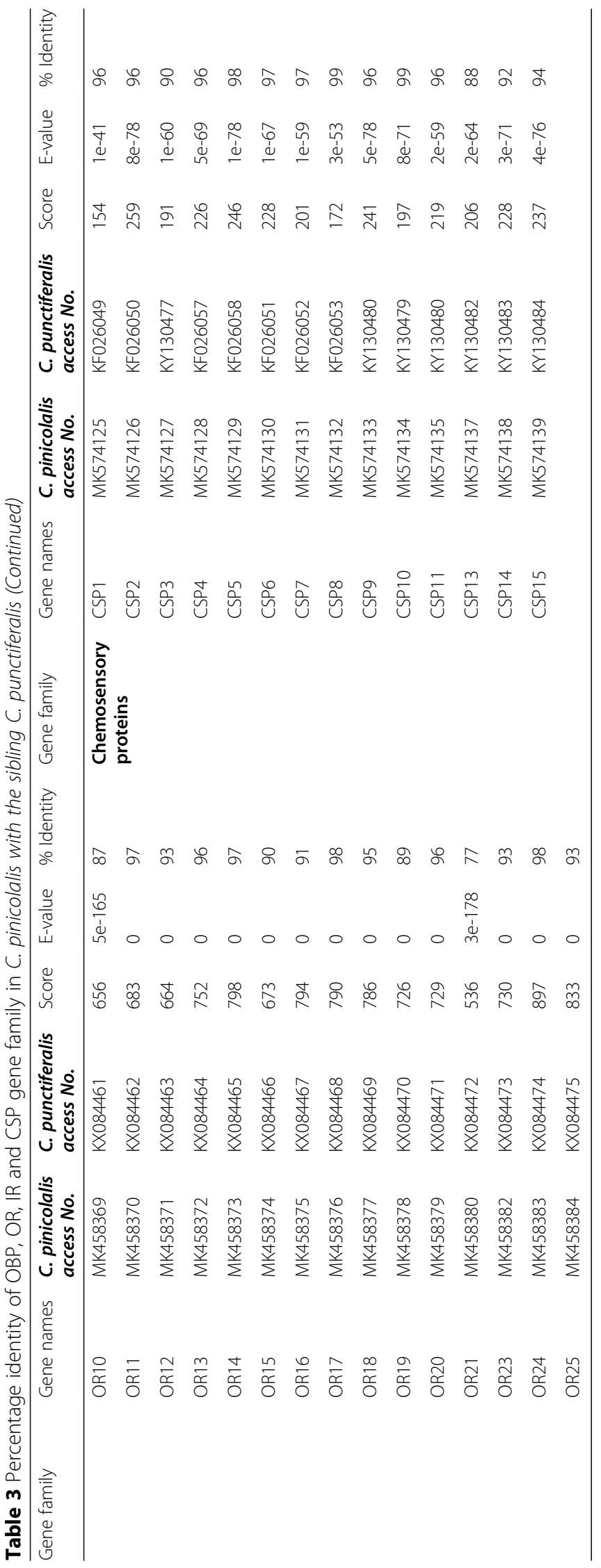




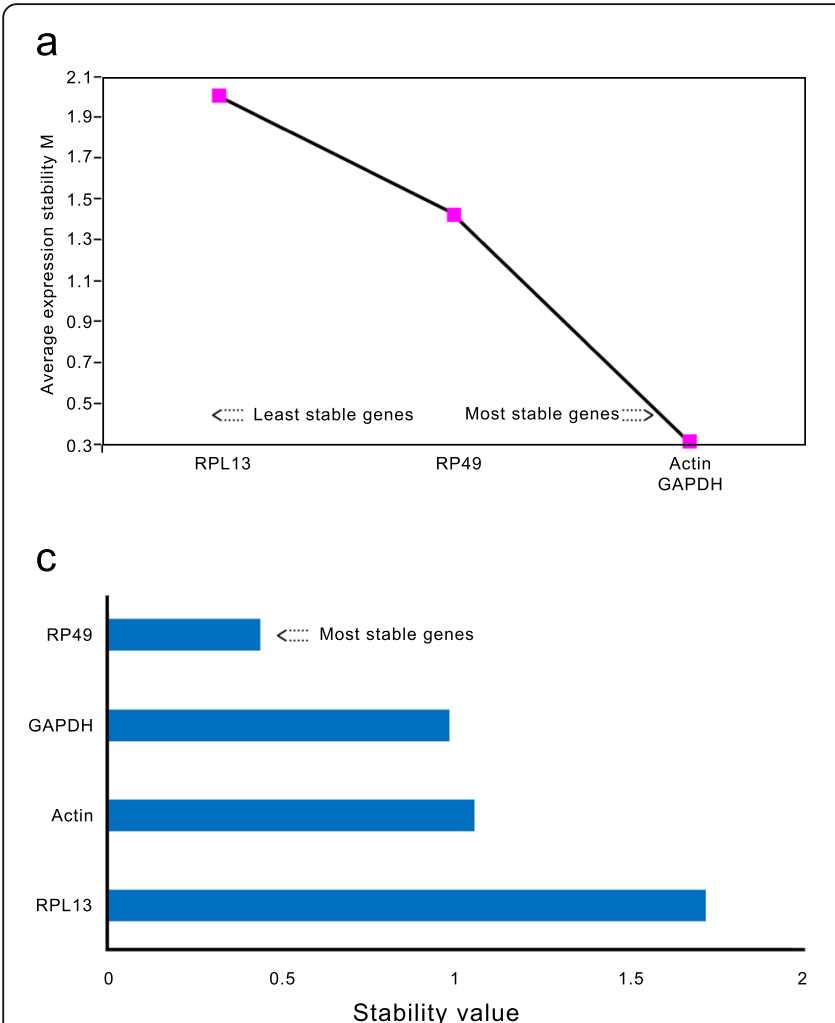

b

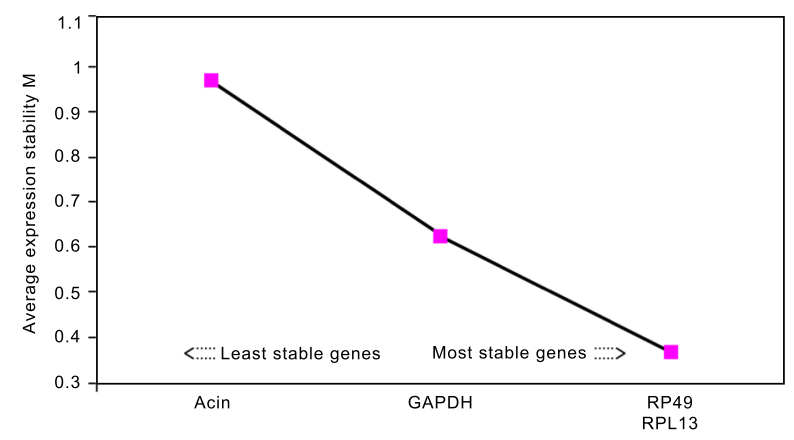

d

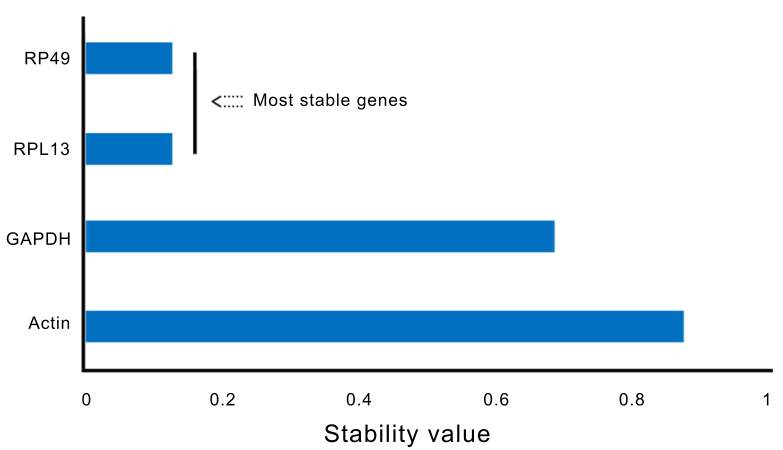

Fig. 4 Stability analysis of candidate reference genes in different developmental stages (a, c) and different adult tissues (b, d) of C. pinicolalis

As in other insects [29-31] OBPs and CSPs were detected in the antennae of both male and female (Additional file 2: Table S1). Among these genes, many of them were sexual biased genes (Fig. 1). PBPs were widely thought to be sex pheromone binding function, normally insects have 3-5 PBP genes. Previous studies suggested that at least one PBP family isoform could well interact with the sex pheromones [32-34]. In our analysis, PBP2 showed significantly male biased expression, and PBP1, PBP3 and PBP4 showed significantly female biased expression. In male moth, the main assignment is to trail the sex pheromones to find a female moth for mating. We speculated the PBP2 might play a critical role in pheromone binding. Females are often selective in seeking a healthy counterpart for mating. GOBP1 and GOBP2 genes, as well as OBP6, OBP7 and OBP9, were also highly expressed in female, this may play some important roles and need for further study. GOBPs are proposed to detect host plants volatiles, food and oviposition sites and PBPs play a key role in detecting sex pheromones [35-37]. However, some studies have demonstrated that GOBPs can interact with sex pheromones and possibly responsible for conducting the function [38]. Our another study have showed that PBP2 and GOBP1 genes may play similar roles in detecting and transporting sex pheromones and host plant volatiles in C. pinicolalis [39]. There are also evolutionary evidence that GOBPs may evolved from PBP by gene duplication, PBP and GOBP2 in Manduca sexta show close relationship and play an important role in coordinated olfactory behaviors [40, 41]. Although the transcriptome of $C$. pinicolalis and C. punctiferlis possess higher similarity, the $C$. pinicolalis adult rely on fresh masson pine branches for laying eggs, which the case is very different in C. punctiferlis adult, they have a wide variety of host plants selection. Therefore, both GOBPs and PBPs from C. pinicolalis and C. punctiferlis might have a greater interest in future research.

CSPs were found in insect contact and sensilla olfactory, but other members exhibited peculiar functions. In Apis mellifera, CSPs have been reported to be involved in larval growth and brood pheromone transportation [42, 43]. In a cockroach Blatta germanica, a CSP is involved in leg regeneration [44]. CSPs binding affinity towards volatile compounds was similar to that of OBPs [45]. In C. pinicolalis antennae transcriptome, we totally identified 19 putative CSPs, and found the transcript per kilobase million (TPM) values of five CSPs (CSP4, CSP5, CSP11, CSP14, and CSP17) were significantly higher in female antennae (Fig. 1b). MsepCSP8 of Mythimna separate was specially expressed in female antennae and showed less sensitive to plant volatiles after RNAi [46]. Also in Locusta migratoria, nearly 17 CSPs abundantly expressed in the female reproductive organs [47]. Higher 
numbers of CSPs in female antennae provide a valuable understanding that CSPs may play an important role in female moths, particularly when it comes to tracking the volatile cues from host-plants and oviposite.

Totally there were 55 OR genes identified from male and female antennal transcriptome dataset, among them 22 ORs showed a significant difference in TPM ratio (Additional file 2: Table S1). In Lepidoptera, OR1 and OR3-8 were identified as pheromone receptors (PR). Our result obviously showed OR1, OR3 and OR6 were specially expressed in male antennae, this may suggest OR1, OR3 and OR6 genes focus on sex pheromones recognition. OR34 also performed biased expression in male antennae, but till now, the function is unknown. More numbers of ORs were highly expressed in female antennae (Fig. 2), this is also discovered in mosquitos [48]. In Bombyx mori, more female biased ORs suggested having function of oviposition cues or male-produced courtship pheromones [49]. This indicated more OR bias in female C. pinicolalis might provide more receptors for the detection of correct host plants and sex pheromones as well.

IRs were proven for its multiple functions such as olfaction, chemosensory modalities, taste and response towards non-chemosensory factors like temperature sensing [50-53]. These IRs are highly sensitive to amines and acids [52]. We have identified 20 IRs in C. pinicolalis that is much more than the number of IRs reported in C. punctiferlis. Indeed, the number of IRs are different in many species. For example, some IRs were exclusively identified in Spodoptera littoralis and Helicoverpa armigera $[54,55]$. Also, many IR genes were identified in gustatory organs in Drosophila melanogaster and the longrange attraction to polyamines is mediated by IR76b and IR41a $[50,56]$. However, in this study the IR gene family from transcriptome data analyzed only from the C. pinicolalis antennae and compared with C. punctiferlis antennal dataset. Based on the transcriptome data analysis, we cannot conclude that there are only 20 (C. pinicolalis) and 11 (C. punctiferlis) [23] IR isoforms in C. pinicolalis and C. punctiferlis antenna. The identified IR isoforms in C. pinicolalis could help to study gene expansion/deletion and existence of other possible IR isoforms in the C. punctiferlis antenna and evolutionary relationship between these two species.

NormFinder and geNorm programs are commonly used to screen and optimize the number of internal reference genes for qRT-PCR analysis [57, 58]. At the same time, the difference between reference genes can be compared, but only one optimal gene can be screened when using the NormFinder [59]. In this research, we used both methods to screen the reference gene. The GeNorm result showed Actin and GAPDH were more stable during different development stages of the C. pinicolalis, and NormFinder showed the RP49 as a stable reference gene. This variation may be due to different algorithms coded in this software. Different software were used for calculating the reference gene stability at different developmental stages in the yellow peach moth, RP49 and GAPDH were found to be more stable [60]. Since the expression of the reference gene differs for developmental stages and tissues, therefore the selection of two or more reference genes is useful to calibrate the expression level. Gao et al. [61] reported three different reference genes (Actin, RPL13 and peptidylprolyl isomerase) for different developmental stages in Aphidius gifuensis. Also, Actin, GAPDH and RP49 reported being the most stable reference gene in the Calliphoridae family [62]. According to our results, it is recommended to use GAPDH or RP49 at different developmental stages of the C. pinicolalis. On another hand, ribosomal proteins are involved in translation and protein synthesis, this recommended us to use RP49 and RPL13 for different tissues in yellow peach moth [60]. Similarly, our findings indicate that both RP49 and RPL13 are the best reference genes for the different body part of the adult.

Furthermore, the female bias genes expression level of OBPs (PBP1, PBP3, PBP4, GOBP1, GOBP2, OBP6, OBP7 and OBP9) were verified by RT-qPCR and extremely consistent with the TMP values obtained from the transcriptome dataset. In addition, the fold change expression results of CSPs, ORs and IRs are consistent with the TMP values (Additional file 2: Figure S2). Therefore, we compared these olfactory-related gene expression levels of $C$. pinicolalis with $C$. punctiferalis, reported by Ge xing et al., 2016 [23]. Gene expression pattern reported from $C$. punctiferalis mostly differs from our study. Noteworthy, most of the ORs (OR2, OR3, OR5, OR6, OR13 and OR15) were significantly expressed in male antenna, whereas in C. punctiferalis the ORs were highly expressed in female antenna. At this point, we suggest these ORs might be functionally active in male moths when comparing with $C$. punctiferalis males. On the other hand, OBPs (OBP2, 5 and 6) and GOBPs (GOBP1 and 2) expression patterns were similar to that of C. punctiferalis. Exclusively, PBP (PBP1, 2, 3 and 4) genes expression was highly recorded in the $C$. punctiferalis male antenna [23]. In contrast, PBP1, 3 and 4 genes were significantly expressed in $C$. pinicolalis female antenna, only PBP3 had a similar expression pattern. However, most of the gene expression patterns of these olfactory-related proteins were different when compared with $C$. punctiferalis dataset [23], since C. pinicolalis is a monophagous pest that mainly feeds on Masson pines. 


\section{Conclusion}

We mainly performed a comprehensive analysis of the antennal transcriptome of $C$. pinicolalis and mined many sexual bias expression olfactory related genes. Meanwhile, transcriptome data analysis revealed that most of the olfactory related genes had more than $90 \%$ identity with the C. punctiferlis. Noteworthy, 4 OBP, 5 OR, 2 IR and 2 CSP genes had 99\% sequence similarity with its sibling species C. punctiferalis. This study provides a starting point to understand the genetic difference at the molecular level and further intensive studies are required to understand the evolutionary relationship between these two species.

\section{Methods}

\section{Insects rearing and antennae collection}

C. pinicolalis larvae were collected from the masson pine in Quanjiao County (32.07 N 117.54 E), Anhui Province, China. Fresh masson pine branch was used to feed the larvae under ambient conditions $27 \pm 0.5^{\circ} \mathrm{C}$, with $70-$ $75 \%$ relative humidity $(\mathrm{RH})$ and a photo period of $16: 8 \mathrm{~h}$ light: dark (L:D). After emergence, the moths were feed on $10 \%$ honey solution [63]. Three days old moths were selected from both sexes (20 moths/sex) and the antennae were excised for RNA extraction.

\section{RNA extraction and first-strand CDNA synthesis}

Total RNA from male and female antennae was isolated using the Quick-RNA ${ }^{\mathrm{Tm}}$ MicroPrep Kit (ZYMO Research, USA) according to the manufacturer's protocol. Ten pairs of antennae were excised from both the sexes. Three biological replicates were maintained (10 pairs/ replication). The integrity of the total RNA was analyzed using $1.5 \%$ agarose gel electrophoresis [64]. The quality and concentration were analyzed on NanoDrop 2000 spectrophotometer (Thermo Scientific, USA). The cDNA was synthesized by following the instructions from RT $^{\mathrm{TM}}$ All-in-One Master Mix Kit (Herogen Biotech, USA). The first strand cDNA synthesis reaction was carried out from $1 \mu \mathrm{g}$ of total RNA. Anchored oligo (dT) from the kit is used and cDNA was synthesized by following the manufacturer's protocol. The final cDNA samples were stored at $-20{ }^{\circ} \mathrm{C}$ until further analysis.

\section{Illumina sequencing}

Transcriptome sequencing was performed at Novogen Co., Ltd. Beijing, China, and the RNA samples (including 3 biological replicates) were sequenced on the Illumina Hiseq 4000 platform. The raw reads were curated by removing adaptor sequences and low quality reads, then assembled into unigenes using Trinity v2.4.0 [65, 66]. Reads with uncertain nucleotides larger than $10 \%$ of the fragment sequence were removed. Trinity de novo program with a default $\mathrm{k}$-mer was used to assemble the clean reads. Sequences redundancy were minimized using CD-HIT program to obtain longest transcript contigs. Annotation-based metrics was adapted for the study. DESeq2 v1.6.3 was used to calculate the identified candidate genes differential expression levels (log2 fold change, $P<0.05)$ [67].

\section{Unigenes annotation and classification}

The unigenes were searched using BLASTX against the non-redundant (nr) NCBI protein database [68]. Using Blast2Go [69], we predicted and classified functions of unigenes by EuKaryotic of orthologous groups (KOG) database [70]. In addition, the online KEGG Automatic Annotation Server (KAAS) was employed for KEGG pathway enrichment analysis following the procedure pathway annotations for unigenes [71, 72].

\section{Identification of olfactory genes and phylogenetic analyses}

The candidate OBPs, ORs and IRs olfactory genes were analyzed using BLASTX, open reading frames (ORFs) were also identified. Phylogenetic tree based on amino acids of these genes was performed with MEGA7.0 software with the neighbour-joining (NJ) method by 1000 replication.

\section{Analysis of differential gene expression}

In order to investigate the expression bias in the antennae of both male and female of $C$. pinicolalis adults, we compared and reported the transcript abundance in units of TPM in both sexes. In the whole dataset of the transcriptome, we identified the interested candidate genes according to their FC, as assessed using corrected $p$-value $(P)$ of $<0.05(n=3)$. Genes were considered as interesting bias expressed at a $\mathrm{FC} \geq 2$ and of potential interest if the genes exhibited $1.5 \leq \mathrm{FC}<2$, both with $P<0.05$.

\section{Reference genes selection in $C$. pinicolalis}

To obtain the stably expressed gene as a reference gene for quantitative real-time PCR (RT-qPCR) and provide a useful message in $C$. pinicolalis study, we selected $\beta$ actin gene (Actin), glyceraldehyde 3- GAPDH, RP49 and RPL13 as candidate reference genes based on reference genes in other insect species. The candidate reference gene expression pattern in different development stages (egg, larva, pupa and adult) and the different body part of the adult (antanna, head, throax, abdomen, leg and wings) of the $C$. pinicolalis were assessed by RT-qPCR. $\mathrm{Ct}$ values were evaluated by using the GeNorm and NormFinder method to identify the stable reference gene for specific tissues (Additional file 3: Table S2). 


\section{RT-qPCR analysis}

The RT-qPCR analysis was performed on select genes to verify the fold changes expression explained in transcriptome data. The primers for RT-qPCR were designed using Primer 3 (http://bioinfo.ut.ee/primer30.4.0/primer3/) (Additional file 3: Table S3). The primers efficiency was tested by using 10 -fold diluted cDNA samples and the standard curve was generated. The Ct values are plotted against the Log of the cDNA dilutions, efficiency percentage and $\mathrm{R}^{2}$ values are within the acceptable range [73]. Quantitative PCR was performed using SybrGreen qPCR Mastermix (DBI Bioscience, Germany), according to manufacturers' protocol on ABI 7500 Fast (Applied Biosystems, USA) by using the following two-step program: denatured for $2 \mathrm{~min}$ at $95^{\circ} \mathrm{C}$ followed by 40 cycles: $10 \mathrm{~s}$ at $95^{\circ} \mathrm{C} ; 30 \mathrm{~s}$ at $60^{\circ} \mathrm{C}$; melting curve analysis was performed from $60^{\circ} \mathrm{C}$ to $95^{\circ} \mathrm{C}$ to determine the specificity of $\mathrm{PCR}$ products. Three independent biological replicates were maintained for all the sample and four technical replicates were performed form each biological sample. The $2^{-\Delta \Delta C T}$ method was used to calculate relative fold change expression [74]. Fold change expression was analysed using $t$-test, software package SPSS v20.0.

\section{Supplementary information}

Supplementary information accompanies this paper at https://doi.org/10. 1186/s12864-020-6648-3.

Additional file 1: Figure S1. A) functional annotation of assembled sequences based on gene ontology (GO) categorization; b) EuKaryotic of orthologous groups (KOG) classification; $\mathbf{c}$ ) is KEGG pathway annotation of the transcriptome. Figure S2. Quantitative RT-qPCR expression levels of olfactory genes from female and male moth of $C$. pinicolalis. The expression levels were statistically significant ( $t$-test, ${ }^{*} P<0.05$, ${ }^{*} P<0.01$, ${ }^{* *} P<0.001$, NS: not significant). Figure S3. Phylogenetic relationship of olfactory-related gene from C. pinicolalis and other insects. A: ORs, B: IRs, C: CSPs. Red font represents the genes from C. pinicolalis; Cpun, Ofur, Bmor, Cmed, Ehip, Harm and Mcin are the abbreviation of C. punctiferalis, O. furnacalis, B. mori, Cnaphalocrocis medinalis, Eogystia hippophaecolus, Helicoverpa armigera, Macrocentrus cingulum, respectively.

Additional file 2: Table S1. Candidate OBPs, CSPS, ORs and IRs genes in Conogethes pinicolalis antennae.

Additional file 3: Table S2. Candidate reference genes in Conogethes pinicolalis antennae. Table S3. Primers for candidate genes by qRT-PCR.

\footnotetext{
Abbreviations

Actin: $\beta$-actin gene; CSPs: Chemosensory proteins; FC: Differential fold change; GAPDH: Glyceraldehyde 3-phosphate dehydrogenase gene; GO: Gene ontology; GOBPs: General odorant-binding proteins; IRs: Ionotropic receptors; KEGG: Kyoto Encyclopedia of Genes and Genomes; KOG: EuKaryotic of orthologous groups; OBPs: Odorant-binding proteins; ODEs: Odorant degrading enzymes; ORs: Odorant receptors; PBPs: Pheromone-binding proteins; PRs: Pheromones receptors; RP49: Ribosomal protein 49 gene; RPL13: Ribosomal protein L13 gene; RTqPCR: Quantitative real-time PCR; SNMPs: Sensory neuron membrane proteins; TPM: Transcript per kilobase million
}

Acknowledgements

Not applicable.

\section{Authors' contributions}

DJ and TZ conceived of the study and led data management; DJ wrote the paper; DJ and SB analyzed the data and produced the figures; DJ, Kh and JL discussed the results; ZW, TZ and SP revised reviewed the article. The authors read and approved the final manuscript.

\section{Funding}

This research was funded by the National Key Research and Development Program of China (2018YFD0200602) and the China Agriculture Research System (CARS-02). The funding is designed to support the research on odorant binding proteins which plays a key role in tracking the host volatiles and mating. The techniques employed in this study will accelerate the understanding of insect odorant binding proteins as the targets for bioactive semio-chemical molecules in the field of pest control management.

\section{Availability of data and materials}

All data generated or analyzed during this study are included in this published article and its supplementary materials. All Illumina data have been deposited in NCBI's Sequence Read Archive (SRA) under accession number SRX5250688, SRX5250689, SRX5250690, SRX5250691, SRX5250692 and SRX5250693.

Ethics approval and consent to participate

Not applicable.

\section{Consent for publication}

All authors approved for publication.

\section{Competing interests}

The authors declare that they have no competing interests.

\section{Author details}

${ }^{1}$ State Key Laboratory for Biology of Plant Diseases and Insect Pests, Institute of Plant Protection, Chinese Academy of Agricultural Sciences, Beijing 100193, China. ${ }^{2}$ College of Plant Protection, Shenyang Agricultural University, Shenyang 110161, China.

Received: 20 March 2019 Accepted: 4 March 2020

Published online: 19 March 2020

\section{References}

1. Jacquin-Joly E, Legeai F, Montagné N, Monsempes C, François MC, Poulain J, Gavory F, et al. Candidate chemosensory genes in female antennae of the noctuid moth Spodoptera littoralis. Int J Biol Sci. 2012;8(7):1036-50.

2. Bruyne MD, Baker TC. Odor detection in insects: volatile codes. J Chem Ecol. 2008;34(7):882-97.

3. Jacquin-Joly E, Merlin C. Insect olfactory receptors: contributions of molecular biology to chemical ecology. J Chem Ecol. 2004;30(12):2359-97.

4. Vogt RG, Riddiford LM. Pheromone binding and inactivation by moth antennae. Nature. 1981;293(5828):161-3.

5. Liu NY, Xu W, Papanicolaou A, Dong SL, Anderson A. Identification and characterization of three chemosensory receptor families in the cotton bollworm Helicoverpa armigera. BMC Genomics. 2014;15(1):597.

6. Jia XJ, Wang HX, Yan ZG, Zhang MZ, Wei CH, Qin XC, Ji WR, et al. Antennal transcriptome and differential expression of olfactory genes in the yellow peach moth, Conogethes punctiferalis (Lepidoptera: Crambidae). Sci Rep. 2016;6:29067.

7. Koizumi K. Yellow peach moth, Dichocrocis punctiferalis (Guenée). Kobe Plant Prot News. 1963;32:58.

8. Honda H, Mrrsuhashi W. Morphological and morphometrical differences between the fruit-and pinaceae-feeding type of yellow peach moth, Conogethes punciferalis (Guenée) (Lepidoptera:Pyralidae). Appl Entomol Zoolog. 1989;24(1):1-10.

9. Konno $\mathrm{YH}, \mathrm{H}$. Honda $\mathrm{H}$, Matsumoto $\mathrm{Y}$. Mechanisms of reproductive isolation between the fruit-feeding and the pinaceae-feeding types of the yellow peach moth, Dichocrocis punctiferalis Guenee (Lepidoptera: Pyralidae). Jpn J Appl Entomol Zool. 1981;25(4):253-8.

10. Inoue H, Yamanaka H. Redescription of Conogethes punctiferalis (Guenée) and descriptions of two new closely allied species from eastern palearctic and oriental regions (Pyralidae, Pyraustinae). Tinea. 2006;19:80-91. 
11. Shashank PR, Doddabasappa B, Kammar V, Honda H. Molecular characterization and management of shoot and fruit borer Conogethes punctiferalis Guenée (Crambidae: Lepidoptera) populations infesting cardamom, castor and other hosts. In: Chakravarthy AK, editor. New horizons in insect science: towards sustainable pest management. India: Academic; 2015. p. 207-27.

12. Murray D, Prowell DP. Molecular phylogenetics and evolutionary history of the neotropical Satyrine subtribe Euptychiina (Nymphalidae: Satyrinae). Mol Phylogenet Evol. 2005;34(1):67-80.

13. Grechko W. The problems of molecular phylogenetics with the example of squamate reptiles: mitochondrial DNA markers. Mol Biol. 2013;47(1):55-74.

14. Solovyeva EN, Poyarkov NA, Dunayev EA, Nazarov RA, Lebedev VS, Bannikova AA. Phylogenetic relationships and subgeneric taxonomy of toad-headed agamas Phrynocephalus (Reptilia, Squamata, Agamidae) as determined by mitochondrial DNA sequencing. Dokl Biol Sci. 2014;455(1): 119.

15. Wang J, Zheng T, Wang ZY, He KL, Yong L, Jing L. Molecular taxonomy of Conogethes punctiferalis and Conogethes pinicolalis (Lepidoptera: Crambidae) based on mitochondrial DNA sequences. J Integr Agric. 2014;13(9):1982-9.

16. Lu JQ, Wang ZY, He KL, Liu Y. Research history, progresses and prospects in the yellow peach moth, Conogethes punctiferalis. Plant Prot. 2010;36(2):31-8.

17. Costa V, Angelini C, De Feis I, Ciccodicola A. Uncovering the complexity of transcriptomes with RNA-Seq. J Biomed Biotechnol. 2010:1-9.

18. Lundberg M, Boss J, Canbäck B, Liedvogel M, Larson KW, Grahn M, et al. Characterization of a transcriptome to find sequence differences between two differentially migrating subspecies of the willow warbler Phylloscopus trochilus. BMC Genomics. 2013;14(1):330.

19. Ansorge WJ. Next-generation DNA sequencing techniques. New Biotechnol. 2009;25(4):195-203.

20. Feng B, Lin X, Zheng K, Qian K, Chang YC, Du YJ. Transcriptome and expression profiling analysis link patterns of gene expression to antennal responses in Spodoptera litura. BMC Genomics. 2015;16:269.

21. Gu SH, Zhou JJ, Gao S, Wang DH, Li XC, Guo YY, et al. Identification and comparative expression analysis of odorant binding protein genes in the tobacco cutworm Spodoptera litura. Sci Rep. 2015;5:13800.

22. Bengtsson JM, Trona F, Montagné N, Anfora G, Ignell R, Witzgall P, JacquinJoly E. Putative chemosensory receptors of the codling moth, Cydia pomonella, identified by antennal transcriptome analysis. PLoS One. 2012; 7(2):e31620.

23. Ge $X$, Zhang TT, Wang ZY, He KL, Bai SX. Identification of putative chemosensory receptor genes from yellow peach moth Conogethes punctiferalis (Guenée) antennae transcriptome. Sci Rep. 2016;6(1):32636.

24. Menken SB, Boomsma JJ, Van Nieukerken EJ, Feder EJVN. Large-scale evolutionary patterns of host plant associations in the lepidoptera. Evolution. 2010;64(4):1098-119.

25. Janz N, Nylin S, Wahlberg N. Diversity begets diversity: host expansions and the diversification of plant-feeding insects. BMC Evol Biol. 2006;6(1):4.

26. Dugdale JS. In: Minks AK, editor. Insect pheromone research, Carde'RT. New York: Academic; 1997. p. 463-72.

27. Roelofs WL, Rooney AP. Molecular genetics and evolution of pheromone biosynthesis in Lepidoptera. PNAS. 2003;100(16):9179-84.

28. Gouin A, Bretaudeau A, Nam K, Gimenez S, Aury JM, Duvic B, Hilliou F, et al. Two genomes of highly polyphagous lepidopteran pests (Spodoptera frugiperda, Noctuidae) with different host-plant ranges. Sci Rep. 2017;7: 11816.

29. Zhang TT, Coates BS, Ge X, Bai SX, He KL, Wang ZY. Male- and femalebiased gene expression of olfactory-related genes in the antennae of Asian corn borer, Ostrinia furnacalis (Guenée) (Lepidoptera: Crambidae). PLoS One. 2015;10(6):e0128550.

30. Li G, Du J, Li Y, Wu J. Identification of putative olfactory genes from the oriental fruit moth grapholita molesta via an antennal transcriptome analysis. PLoS One. 2015;10(11):e0142193.

31. Cao DP, Liu Y, Wei JJ, Liao XY, William W, Li JH, Wang GR. Identification of candidate olfactory genes in Chilo suppressalis by antennal transcriptome analysis. Int J Biol Sci. 2014;10(8):846.

32. Yusuke S, Takeshi S, Takaaki D, Hidefumi M, Takeshi F, Shigeru M, Hideki S, et al. In vivo functional characterization of pheromone binding protein-1 in the silkmoth, Bombyx mori. Sci Rep. 2018;8(1):13520.

33. Yu Y, Ma F, Cao YX, Zhang JH, Zhang YG, Duan SN, Wei YD, et al. Structural and functional difference of pheromone binding proteins in discriminating chemicals in the gypsy moth, Lymantria dispar. Int J Biol Sci. 2012;8(7):97991.

34. Zhang $T$, Sun $Y Q$, Wanner $K W$, Brad $C$, He KL, Wang ZY. Binding affinity of five PBPs to Ostrinia sex pheromones. BMC Mol Biol. 2017;18:4.

35. Vogt RG, Rybczynski R, Lerner MR. Molecular cloning and sequencing of general odorant-binding proteins GOBP1 and GOBP2 from the tobacco hawk moth Manduca sexta: comparisons with other insect OBPs and their signal peptides. J Neurosci. 1991;11(10):2972-84.

36. Leal WS. Odorant reception in insects: roles of receptors, binding proteins, and degrading enzymes. Annu Rev Entomol. 2013;58(1):373-91.

37. Zhou JJ. Odorant-binding proteins in insects. Vitam Horm. 2010:241-7.

38. Liu NY, Yang F, Yang K, He P, Niu XH, Xu W, Anderson A, Dong SL. Two subclasses of odorant-binding proteins in Spodoptera exigua display structural conservation and functional divergence. Insect Mol Biol. 2015; 24(2):167-82.

39. Jing DP, Zhang TT, Prabu S, Bai SX, He KL, Wang ZY. Molecular characterization and volatile binding properties of pheromone binding proteins and general odorant binding proteins in Conogethes pinicolalis (Lepidoptera: Crambidae). Int J Biol Macromol. 2020;146:263-72.

40. Merritt TJ, LaForest S, Prestwich GD, Quattro JM, Vogt RG. Patterns of gene duplication in lepidopteran pheromone binding proteins. J Mol Evol. 1998; 46:272-6.

41. Vogt RG, Rogers ME, Franco M, Sun M. A comparative study of odorant binding protein genes: differential expression of the PBP1-GOBP2 gene cluster in Manduca sexta (Lepidoptera) and the organization of OBP genes in Drosophila melanogaster (Diptera).J Exp Biol.2002;205:719-44.

42. Briand L, Swasdipan N, Nespoulous C, Bézirard V, Blon F, Huet JC, et al. Characterization of a chemosensory protein (ASP3C) from honeybee (Apis mellifera L.) as a brood pheromone carrier. Eur J Biochem. 2002; 269:4586-96.

43. Forêt S, Wanner KW, Maleszka R. Chemosensory proteins in the honey bee: insights from the annotated genome, comparative analyses and expressional profiling. Insect Biochem Mol Biol. 2007;37:19-28.

44. Kitabayashi AN, Arai T, Kubo T, Natori S. Molecular cloning of cDNA for p10, a novel protein that increases in regenerating legs of Periplaneta americana (American cockroach). Insect Biochem Mol Biol. 1998;28:785-90.

45. Pelosi P, Zhou JJ, Ban LP, Calvello M. Soluble proteins in insect chemical communication. Cell Mol Life Sci. 2006;63:1658-76.

46. Aneela Y, Waris MI, Muhammad TUQ, Muhammad S, Prager SM, Man-Qun W. Functional analysis of the chemosensory protein msepcsp8 from the oriental armyworm Mythimna separata. Front Physiol. 2018;9:872.

47. Zhou XH, Ban LP, Immacolata I, Zhao LJ, Gao Q, Antonio F, Simona S, et al. Diversity, abundance, and sex-specific expression of chemosensory proteins in the reproductive organs of the locust Locusta migratoria manilensis. Biol Chem. 2013;394(1):43-54.

48. latrou K, Biessmann H. Sex-biased expression of odorant receptors in antennae and palps of the African malaria vector anopheles gambiae. Insect Biochem Mol Biol. 2008;38(2):268-74.

49. Wanner KW, Anderson AR, Trowell SC, Theilmann D, Robertson HM, Newcomb R. Female-biased expression of odorant receptor genes in the adult antennae of the silkworm, Bombyx mori. Insect Mol Biol. 2007;16(1): 107-19.

50. Benton R, Vannice KS, GomezDiaz C, Vosshall LB. Variant ionotropic glutamate receptors as chemosensory receptors in Drosophila. Cell. 2009; 136(1):149-62.

51. Abuin L, Bargeton B, Ulbrich MH, Isacoff EY, Kellenberger S, Benton R. Functional architecture of olfactory ionotropic glutamate receptors. Neuron. 2011;69:44-60.

52. Silbering AF, Rytz R, Grosjean $Y$, Abuin L, Ramdya P, Jefferis GS, Benton R. Complementary function and integrated wiring of the evolutionarily distinct Drosophila olfactory subsystems. J Neurosci. 2011;31:13357-75.

53. Min S, Ai M, Shin SA, Suh GS. Dedicated olfactory neurons mediating attraction behavior to ammonia and amines in Drosophila. Proc Natl Acad Sci. 2013:110:E1321-9.

54. Liu Y, Cu S, Zhang Y, Guo Y, Wang G. Candidate olfaction genes identified within the Helicoverpa armigera antennal transcriptome. PLoS One. 2012; 7(10):e48260.

55. Olivier V, Monsempes C, François MC, Poivet E, Jacquin-Joly E. Candidate chemosensory ionotropic receptors in a Lepidoptera. Insect Mol Biol. 2011; 20(2):189-99. 
56. Hussain A, Zhang M, Uecpunar HK, Svensson T, Quillery E, Gompel N, et al. lonotropic chemosensory receptors mediate the taste and smell of polyamines. PLoS Biol. 2016;14:e1002454.

57. Vandesompele J, DePreter K, Pattyn F, Poppe B, Van Roy N, paepe AD, Speleman F. Accurate normalization of real-time quantitative RT-PCR data bygeometric averaging of multiple internal control genes. Genome Biol. 2002;3(7).

58. Andersen $\mathrm{CL}$, Jensen $\mathrm{J}$, Orntoft TF. Normalization of real-time quantitative reverse transcription-PCR data: a model-based variance estimation approach to identify genes suited for normalization, applied to bladder and colon cancer data sets. Cancer Res. 2004;64(15):5245-50.

59. Silvia P, Royo L, Astudillo A, Escudero D, Jesús O. Identifying the most suitable endogenous control for determining gene expression in hearts from organ donors. BMC Mol Biol. 2007:8(1):114.

60. Yang $L, H u X J, X u Z F$, He L, Xiao W. Screening of reference genes for qRTPCR in Conogethes punctiferails (Lepidoptera: Crambidae). Acta Entomol Sin. 2017:60(11):1266-77.

61. Gao XK, Zhang S, Luo JY, Wang CY, Lü LM, Zhang $\sqcup$, Zhu XZ, et al. Identification and validation of reference genes for gene expression analysis in Aphidius gifuensis (Hymenoptera: Aphidiidae). PLoS One. 2017;12(11): e0188477.

62. Cardoso GA, Matiolli CC, Torres TT. Selection and validation of reference genes for functional studies in the Calliphoridae family. J Insect Sci. 2014; 14(2):1-15.

63. Braccini CL, Vega AS, Coll Aráoz MV, Teal PE, Cerrillo T, Zavala JA, Fernandez PC. Both volatiles and cuticular plant compounds determine oviposition of the willow sawfly Nematus oligospilus on leaves of Salix spp. (Salicaceae). J Chem Ecol. 2015:41(11):985-96.

64. Cui L, Rui C, Yang D, Wang Z, Yuan H. De novo transcriptome and expression profile analyses of the Asian corn borer (Ostrinia furnacalis) reveals relevant flubendiamide response genes. BMC Genomics. 2017;18(1):20.

65. Huang HJ, Lu JB, Li Q, Bao YY, Zhang CX. Combined transcriptomic/ proteomic analysis of salivary gland and secreted saliva in three planthopper species. J Proteome. 2018;172:25-35.

66. Grabherr MG, Haas BJ, Yassour M, Levin JZ, Thompson DA, Ido A, Xian A et al. Full-length transcriptome assembly from RNA-Seq data without a reference genome. Nat Biotechnol. 2011;29(7):644.

67. Love Ml, Huber W, Anders S. Moderated estimation of fold change and dispersion for RNA-seq data with DESeq2. Genome Biol. 2014;15(12):550.

68. Liu M, Qiao G, Jiang J, Yang H, Xie L, Xie JZ, Zhuo RY. Transcriptome sequencing and De novo analysis for Ma bamboo (Dendrocalamus latiflorus Munro) using the Illumina platform. PLoS One. 2012;7(10):e46766.

69. Ana C, Stefan GT, Juan Miguel GG, Javier T, Manuel T, Montserrat R. Blast2GO: a universal tool for annotation, visualization and analysis in functional genomics research. Bioinformatics. 2005;21(18):3674-6.

70. Ashburner M, Ball CA, Blake JA, Botstein D, Butler H, Cherry JM, Davis AP, et al. Gene ontology: tool for the unification of biology. The gene ontology consortium. Nature Genet. 2000;25(1):25-9.

71. Minoru K, Michihiro A, Susumu G, Masahiro H, Mika H, Masumi I, Toshiaki K, et al. KEGG for linking genomes to life and the environment. Nucleic Acids Res. 2007;36(Database issue):D480-4.

72. Shevchenko A, Tomas H, Havli J, Olsen JV, Mann M. In-gel digestion for mass spectrometric characterization of proteins and proteomes. Nat Protoc. 2006;1(6):2856-60.

73. Bustin S, Benes V, Garson J, Hellemans J, Huggett J, Kubista M, Mueller R, et al. The MIQE guidelines: minimum information for publication of quantitative real-time PCR experiments. Clin Chem. 2009;55(4):611-22.

74. Livak KJ, Schmittgen TD. Analysis of relative gene expression data using real-time quantitative PCR and the $2^{-\Delta \Delta C T}$ method. Methods. 2001;25(4): $402-8$.

\section{Publisher's Note}

Springer Nature remains neutral with regard to jurisdictional claims in published maps and institutional affiliations.

Ready to submit your research? Choose BMC and benefit from:

- fast, convenient online submission

- thorough peer review by experienced researchers in your field

- rapid publication on acceptance

- support for research data, including large and complex data types

- gold Open Access which fosters wider collaboration and increased citations

- maximum visibility for your research: over $100 \mathrm{M}$ website views per year

At BMC, research is always in progress.

Learn more biomedcentral.com/submissions 